\title{
MASIER
}

\section{Basalt Waste Isolation Program Monthly Report}

August 1978

Prepared for the United States

Department of Energy

Under Contract EY-77-C-06-1030

\section{Rockwell International}

Rockwell Hanford Operations

Energy Systems Group

Richland, WA 99352 


\section{DISCLAIMER}

This report was prepared as an account of work sponsored by an agency of the United States Government. Neither the United States Government nor any agency Thereof, nor any of their employees, makes any warranty, express or implied, or assumes any legal liability or responsibility for the accuracy, completeness, or usefulness of any information, apparatus, product, or process disclosed, or represents that its use would not infringe privately owned rights. Reference herein to any specific commercial product, process, or service by trade name, trademark, manufacturer, or otherwise does not necessarily constitute or imply its endorsement, recommendation, or favoring by the United States Government or any agency thereof. The views and opinions of authors expressed herein do not necessarily state or reflect those of the United States Government or any agency thereof. 


\section{DISCLAIMER}

Portions of this document may be illegible in electronic image products. Images are produced from the best available original document. 


\title{
Rockwell International
}

\author{
Rockwell Hanford Operations \\ Energy Systems Group \\ Richland, WA 99352
}

\section{PREPARED FOR THE UNITED STATES DEPARTMENT OF ENERGY \\ UNDER CONTRACT EY-77-C-06-1030}

\section{PRELIMINARY REPORT}

This Report contains information of a preliminary nature. It is subject to revision or correction and therefore does not represent a final Report. It was prepared primarily for internal use within The Rockwell Hanford Operations. Any expressed views and opinions are those of the Author and not necessarily of the Company.

\section{NOTICE}

This Report was prepared as an account of work sponsored by the United States Government. Neither the United States nor the United States Department of Energy, nor any of their Employees, nor any of their Contractors, Subcontractors, or their Employees, makes any warranty, express or implied, or assumes any legal liability or responsibility for the accuracy, completeness, or usefulness of any information, apparatus, product or process disclosed, or represents that its use would not infringe privately owned rights. 


\section{BASALT WASTE ISOLATION PROGRAM: MONTHLY REPORT}

R. A. Deju, Director

Basalt Waste Isolation Program

August 31,1978

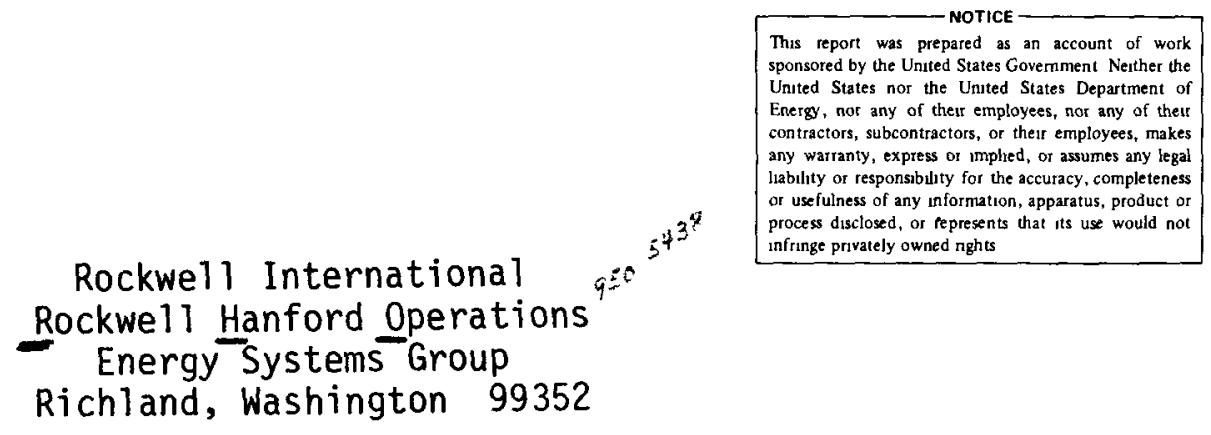


TABLE OF CONTENTS

Page

INTRODUCTION

PROGRAM SUMMARY

SITE STUDIES PROJECT

5

DRILLING PROJECT

7

TECHNOLOGY DEVELOPMENT PROJECT

NEAR-SURFACE TEST FACILITY PROJECT

REPOSITORY PROJECT

14

MANPOWER SUMMARY

VISITORS

TRAVELERS

DOCUMENTS ISSUED 


\section{INTRODUCTION}

In February 1976, the U. S. Energy Research and Development Administration (currently the U.S. Department of Energy) expanded the commercial radioactive waste management programs and established the National Waste Terminal Storage Program. Its mission was to provide multiple facilities in various deep geologic formations within the United States. The Office of Waste Isolation was established within the Union Carbide Corporation-Nuclear Division to provide program management to the National Waste Terminal Storage Program. The overall program consisted of investigating a number of geologic rock types to determine their suitability for terminal storage of radioactive waste. Basalts, such as the Columbia Plateau basalts which underlie a large portion $\delta$ the Pacific Ilorthwest and the Hanford reservation, were selected for initial geologic reconnaissance. Atlantic Richfield Hanford Company was asked in May 1976 by the Office of Waste Isolation to plan and execute a basalt feasibility study. Geologic exploration of Columbia Plateau basalts was needed to determine the feasibility of utilizing those formations as a site for terminal storage of commercial nuclear waste.

In September 1977, the National Waste Terminal Storage Program (now the U. S. Terminal Storage Program) was restructured. While emphas is was still on a salt repository, additional funds were given to support investigations of two U. S. Department of Energy sites (Hanford and Nevada). The Budget Reporting Classification Number for the Hanford study is $A G-02-02-10$.

The Hanford program is the responsibility of the U. S. Department of EnergyRichland Operations Office. Rockwell Hanford Operations (successor to the Atlantic Richfield Hanford Company) established the Basalt Waste Isolation Program and chartered it with the responsibility for conducting the basalt feasibility studies. Rockwell Hanford Operations is the prime contractor responsible for the Hanford basalt studies. The program is divided into five projects:

Site Studies;

Urilling;

Technology Development;

Near-Surface Test Facility;

Repository.

A summary of major program accomplishments during the reporting period follows. 
Preliminary geologic maps of the western Pasco Basin have been completed. These maps consist of one series depicting Columbia River Basalt outcrop areas (28 sheets at 7-1/2-minute quadrangle scale) and one series depicting late Cenozoic sediment outcrop areas (13 sheets at 15-minute quadrangle scale).

U-2 aerial photography of the Pasco Basin and surrounding areas of the Columbia Plateau has been completed. Very high-resolution color infrared and black and white imagery was obtained.

Drilling operations at DC-4 advanced from 1,074 feet to 1,664 feet. $D C-4$ is 33 percent complete, based upon a total depth of 4,000 feet.

Science Applications, Inc. finished hydrological testing in Core Hole $\mathrm{DC}-2$ on August $21,1978$.

Subcontractor reports have been received on the characterization of repository simulation experiments at 200 and 300 degrees Centigrade for 30 days. Optical examinations indicate no visible alteration of spent unreprocessed fuel, zircalloy, and stainless steel in contact with basalt. Interpretation of results, as well as equilibrium and kinetics studies, is continuing.

The Title I design effort for Phase I (electric heater testing) by Vitro Engineering was completed on August 14, 1978. This included the power, lighting, onsite communications, facility ventilation, and site work. Title I cost estimate is in preparation and Title II design has been initiated with scheduled completion in December 1978.

The upgrading of the existing electrical distribution line by Rockwell Hanford Operations' plant forces is essentially complete. The 2.4-kilovolt line is activated and the 13.8-kilovolt line is ready for service. Only some minor activity and cleanup remains. The construction of the new portion of the electric distribution line is approximately 30 percent complete; 21 of the 37 poles are in place.

Approximately 40 percent of the material to be excavated from the tunnel open cuts has been removed. Excavation at the east portal is essentially complete and rock bolting under way.

A report detailing the description and comparison of computer codes used for rock mechanics design was completed. The report discusses the finite difference, finite element, displacement discontinuity, and boundary integral codes in use and gives a cost comparison for each.

\section{MAJOR PROBLEM AREAS}

None. 


\section{OBJECTIVE}

All site studies are provided to support site selection and evaluation as well as to prepare for the preliminary safety analysis report, environmental report, and draft environmental impact statement. These studies are aimed at establishing areas that potentially will provide geologic and hydrologic barriers adequate to prevent release of the waste to the biosphere. When a site is selected, site studies will thoroughly characterize that site geologically and hydrologically and provide service to construction activities during construction. At the same time, the studies will develop a monitoring plan that will be initiated as soon as a final site is selected and continue through the life of the repository. The monitoring is to continually evaluate natural risks and provide early warning of any potential hazard to the waste confinement.

\section{DESCRIPTION OF WORK ACCOMPLISHED}

\section{Preliminary Site Characterization}

A structure contour map of the top of basalt beneath the Hanford Site has been completed at a scale of 1:100,000.

The "Bibliography of the Geology of the Columbia Basin and Surrounding Areas of Washington with Selected References to Columbia Basin Geology of Idaho and Oregon," RHO-BWI-C-10, has been printed and distributed.

Preliminary geologic maps of the western Pasco Basin have been completed. These maps consist of one series depicting Columbia River Basalt outcrop areas (28 sheets at 7-1/2-minute quadrangle scale) and one series depicting late Cenozoic sediment outcrop areas (13 sheets at 15-minute quadrangle scale).

U-2 aerial photography of the Pasco Basin and surrounding areas of the Columbia Plateau has been completed. Very high-resolution color infrared and black and white imagery was obtained.

Permeability testing of Core Hole DC-2 was completed and results are presently being analyzed.

Washington State Department of Natural Resources has completed mapping of late Cenozoic sediments within 75 percent of the eastern half of the Columbia Plateau, Washington State.

\section{PROBLEM AREAS AND ACTION TAKEN}

None. 
Site Studies Project (continued)

PLANNED WORK FOR SUBSEQUENT MONTHS

Geologic mapping of the Columbia Plateau will continue into September 1978. Preparation of statements of work for fiscal year 1979 contracts will be completed in September. Fiscal year 1978 geologic investigations will be integrated, summarized, and documented. 
REPORTING PERIOD

DRILLING PROJECT

AUGUST $1-31,1978$

\section{OBJECT IVE}

The Drilling Project provides the boreholes necessary to investigate the subsurface geologic, hydrologic, and engineering properties of the Columbia River basalts. This investigation is being conducted to determine the suitability of the basalts for the construction of an environmentaliy acceptable waste repository. These studies are in direct support to the Site Studies Project for preliminary and final site characterization.

The Drilling Project will also provide services in the area of drilling technology which will assist the Repository Project and the Near-Surface Test Facility Project.

\section{DESCRIPTION OF WORK ACCOMPLISHED}

\section{Drilling}

Drilling operations were conducted at three locations and hydrologic testing at two locations during the reporting period.

Coring operations at DC- 4 advanced from 1,074 feet to 1,664 feet. $D C-4$ is 33 percent complete, based upon a total depth of 4,000 feet.

Coring operations at DC- 8 were completed at the planned depth of 4,100 feet on August 4, 1978.

Deviated coring in DC-2 was initiated on August 22, 1978.

\section{Geophysical Logging}

Welex Services ran temperature, compensated density, dual induction guard, compensated acoustic velocity and dip logs in Boreholes DC-5 and DC- 7 .

\section{Hydrological Testing}

Science Applications, Inc. finished hydrological testing in Core Hole DC-2 on August 21, 1978.

Lawrence Berkeley Laboratory is performing hydrological testing in Core Hole DC-6. Five intervals were tested during the reporting period. 
Drilling Project (continued)

\section{PROBLEM AREAS AND ACTION TAKEN}

- The inflation line for the Lawrence Berkeley Laboratory test packer in DC-6 parted while setting the packer. While pulling the packer assembly, the packer came loose and wedged at $315 \pm$ feet. When attempting to pull the packer, 20 joints of damaged 3-1/2-inch casing came loose and were retrieved. Excessive drill rod wear was apparent on many of the casing pin connections.

- McCullough Services ran a cement bond log which indicated the top of cement outside the 3-1/2-inch casing to be at 1,070 feet. The 3-1/2inch casing was chemically cut at 1,020 feet and removed. New 3-1/2inch casing was installed.

\section{PLANNED WORK FOR SUBSEQUENT MONTHS}

Coring operations will continue at DC-4. Lawrence Berkeley Laboratory will complete hydrologic testing in DC-6. Deviated coring operations will continue at $D C-2$. Gyro-directional surveys will be run in $D C-2, D C-3, D C-4$, DC-5, DC-6, DC-7, DC-8, and DDH-3 in mid-September 1978. 


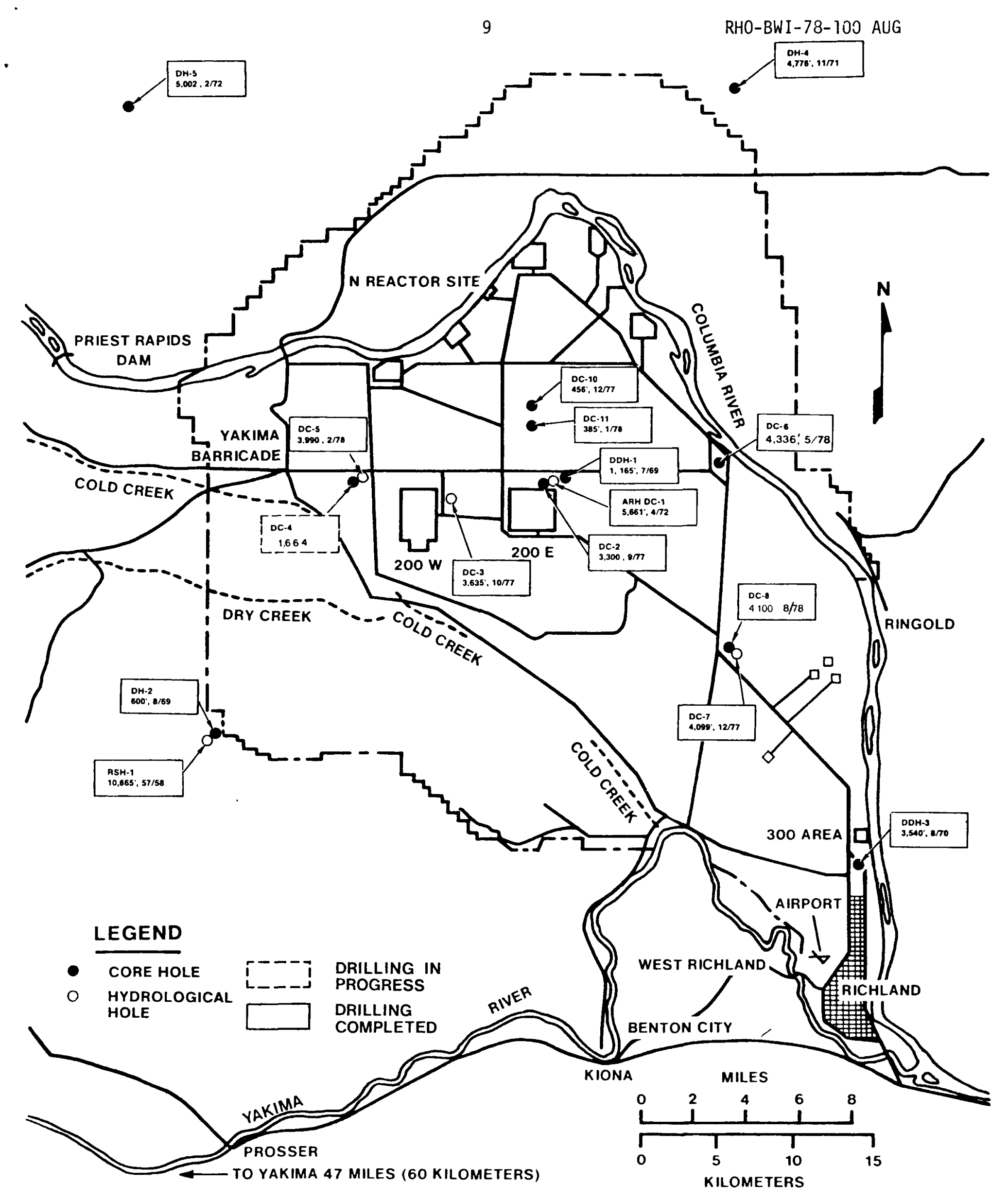




\section{OBJECTIVE}

Technology Development supports the mission of building a repository by providing solutions to technical problems related to the design and monitoring of the repository. Data developed during solution of technical problems will also be used in the safety analysis report and the environmental report.

\section{DESCRIPTION OF WORK ACCOMPLISHED}

\section{Rock Testing}

The remainder of the second shipment of 27 boxes of core from $\mathrm{DH}-4, \mathrm{DH}-5$, $D C-2, D D H-3$, and $D C-11$ has been characterized. Most of the laboratory test samples have been prepared and approximately 120 mechanical rock property tests have been completed.

\section{Downhole Laboratory}

Testing of specific components for the downhole laboratory has been completed. The final report describing the results of the testing has been received and is in review. The downhole laboratory instruments and trailer have been received.

\section{Borehole Plugging}

The proposals are still being evaluated.

\section{Multiple Barrier Studies}

The characterization effort on deep basalt alteration minerals was continued. These efforts are vital to the definition of the basalt/ground water environment in potential repository horizons. The studies will establish reference compositions for further multiple barrier studies. Low-temperature equilibrium experiments ( 25 degrees Centigrade) measuring radionuclide distribution coefficients on basalt, heulandite, and nontronite have also continued. Al1 radionuclides equilibrated with these materials to date have shown a much greater adsorption on basalt than on nontronite or heulandite on a unit surface area basis. Subcontractor reports also have been received on the characterization of repository simulation experiments at 200 and 300 degrees Centigrade for 30 days. Optical examinations indicate no visible alteration of spent unreprocessed fuel, zircalloy, and stainless steel in contact with basalt. Interpretation of results, as well as equilibrium and kinetics studies, is continuing. 
Technology Development Project (continued)

\section{In Situ Testing}

The work statement for the fiscal year 1979 heater tests in the Near-Surface Test Facility was drafted and reviewed. A revised set of drawings for the instrument borehole arrays was received from the Lawrence Berkeley Laboratory.

The first draft of the test plan for the spent fuel tests was completed and is now in review.

PROBLEM AREAS AND ACTION TAKEN

- The Lawrence Berkeley Laboratory area of responsibility is being rescoped.

- Discussions are under way.

\section{PLANNED WORK FOR SUBSEQUENT MONTHS}

The work plan for the heater tests in the Near-Surface Test Facility will be completed. The test plan for the spent fuel tests will be completed. The report on the results of testing instruments for the downhole laboratory will be reviewed and a new direction selected for the work effort. Laboratory testing of the rock cores sent to the Colorado School of Mines will be completed and a draft of the final report describing the results of fiscal year 1978 testing will be completed. The work plan for underground mapping of the Near-Surface Test Facility will be completed and underground mapping will begin. 
REPORTING PERIOD

NEAR-SURFACE TEST FACILITY PROJECT

AUGUST 1-31, 1978

\section{OBJECTIVE}

To design and construct a multipurpose test facility for in situ testing of basalt.

\section{DESCRIPTION OF WORK ACCOMPLISHED}

\section{Facility Design and Site Work}

The Title I design effort for Phase I (electric heater testing) by Vitro Engineering was complete on August 14, 1978. This included the power, lighting, onsite communications, facility ventilation, and site work. Title I cost estimate is in preparation and Title II design has been initiated with scheduled completion in December 1978.

Planning activities for Phase II (radioactive material testing) continued with the issuance of the Phase II Master Project Schedule (August 16, 1978) to the U. S. Department of Energy. The start of formal conceptual design activities is being delayed, pending approval of the functional design criteria by the U. S. Department of Energy.

Remote Handling

The contract with Atomics International for remote handling engineering studies was finalized. Work is to be initiated in September 1978 with scheduled completion in December 1978. Work was initiated on preparing a statement of work for the remote handling system design and fabrication contract to be awarded in fiscal year 1979 .

\section{Construction}

The upgrading of the existing electrical distribution line by Rockwell Hanford Operations' plant forces is essentially complete. The 2.4-kilovolt line is activated and the 13.8-kilovolt line is ready for service. Only some minor activity and cleanup remains. The construction of the new portion of the electric distribution line is approximately 30 percent complete, and 21 of the 37 poles are in place.

Approximately 40 percent of the material to be excavated from the tunnel open cuts has been removed. Excavation at the east portal is essentially complete and rock bolting under way.

Safety and Environmental Analys is

The Near-Surface Test Facility Safety Assessment Document format was issued to Rockwell Hanford Operations for distribution and transmittal to the

U. S.Department of Energy for information. 
Near-Surface Test Facility Project (continued)

Safety and Environmental Analys is

A safety plan was prepared for the Near-Surface Test Facility. This plan provides the integration of the Genstar Construction Company, J. A. Jones Construction Company, and Rockwell Hanford Operations' safety plans, and defines the safety interfaces, authority, and responsibilities of the various groups. The plan was developed, reviewed, and transmitted to the U. S. Department of Energy.

An emergency plan for the Near-Surface Test Facility was also developed, reviewed, and transmitted to the U. S. Department of Energy.

Activities have begun to implement the training required in mine rescue, mine firefighting, and other safety-related emergency activities. These began with the attendance of two Rockwell Hanford Operations' personnel at the ANSUL Mine Firefighting School.

PROBLEM AREAS AND ACTION TAKEN

None.

PLANNED WORK FOR SUBSEQUENT MONTHS

Title II design work on Phase I by Vitro Engineering is to continue and conceptual design work on Phase II is to be initiated. Remote handling engineering studies by Atomics International are to be initiated in September 1978. Construction of the Near-Surface Test Facility tunnels and excavations is to continue and work in all three tunnels is scheduled for startup in September 1978. 


\section{OBJECTIVE}

The objectives of this program are to select and evaluate a repository site in basalt, establish design criteria, and construct a repository for storage of nuclear waste.

\section{DESCRIPTION OF WORK ACCOMPLISHED}

\section{Repository Siting}

Work was started on selection of a site for testing of methods for site characterization. Criteria have been prepared and issued to the team that will make the selection. Two areas will be utilized: a large area of about 100 square miles for testing of macro-evaluation techniques; and, a smaller area of several square miles for testing local characteristics.

\section{Engineering Studies}

After initial review of the third draft of the functions and design criteria for the repository, it was found that additional modifications we re required prior to issuing for review. The fourth draft has been prepared and was disseminated for review on August 30, 1978.

The draft plan for the preconceptual design was prepared. This plan explains the basic requirements of the five subprograms within the repository and what is to be accomplished by subcontractor architect/engineer firms.

A draft report of functions and design criteria for repository ventilation has been submitted to Rockwell Hanford Operations. This report will be used as a basis for preconceptual ventilation studies.

A report detailing the description and comparison of computer codes used for rock mechanics design was completed. The report discusses the finite difference, finite element, displacement discontinuity, and boundary integral codes in use and gives a cost comparison for each.

The report "Rock Mechanics Methods and In Situ Heater Tests for Design of a Nuclear Waste Repository in Basalt," RHO-BWI-LD-2, has been issued.

Detailed axisymmetric model runs of the proposed spent fuel test facility canister borehole, liner, and insulating plug have been completed. Results show that the liner has little effect on the transfer of heat vertically from the borehole, but creates a more uniform temperature distribution around the canister borehole.

The development of a document detailing rock mechanics design criteria for an underground basalt repository was initiated during the month. The document is jointly being written by the University of Minnesota, Dames and Moore, and Dr. J. F. T. Agapito. Completion date is scheduled for December 1979. 
Repository Project (continued)

Architect/Engineer Selection Support

A draft of the conceptual design contract award schedule was prepared and provided to the U. S. Department of Energy.

A draft work statement for the architect/engineer work was prepared and provided to the U. S. Department of Energy.

Safety and Environmental Analys is

The statement of work for the second phase of the risk assessment program is ready for submission to prospective contractors for their evaluation and submission of proposals. The outline for the license application has been completed and will be issued early in September 1978.

PROBLEM AREAS AND ACTION TAKEN

None.

\section{PLANNED WORK FOR SUBSEQUENT MONTHS}

Kickoff meetings will be held for the site selection study with the contractor. The preconceptual design plan is to be completed. The outline for the license application is to be submitted to the U. S. Department of Energy. The Phase II parametric design study report will be issued. A draft copy of the final fiscal year 1978 numerical modeling studies report will be received. 
Man-Months

ROCKWELL HANFORD OPERATIONS

74.0

DR. J. F. T. AGAPITO

2.0

MR. R. BLACK

0.2

COLORADO SCHOOL OF MINES

8.0

FENIX \& SCISSON, INC. AND SUBCONTRACTORS

28.0

GEOSCIENCE RESEARCH CONSULTANTS

5.0

IDAHO BUREAU OF MINES AND GEOLOGY

0.5

J. A. JONES CONSTRUCTION COMPANY

1.0

LAWRENCE BERKELEY LABORATORY

14.0

OREGON DEPARTMENT OF GEOLOGY AND MINERAL INDUSTRIES

1.0

PACIFIC NORTHWEST LABORATORY

3.0

THE PENNSYLVANIA STATE UNIVERSITY

5.0

RICHLAND ENGINEERING

0.3

SENTURION SCIENCES

3.0

W. K. SUMMERS AND ASSOCIATES

1.0

UNIVERSITY OF MINNESOTA

7.0

UNIVERSITY OF OREGON

4.0

U. S. GEOLOGICAL SURVEY - WATER RESOURCES DIVISION

5.0

U. S. GEOLOGICAL SURVEY - WESTERN DIVISION

5.0

VITRO ENGINEERING

16.5

WASHINGTON STATE DEPARTMENT OF ECOLOGY

WASHINGTON STATE DEPARTMENT OF NATURAL RESOURCES

WASHINGTON STATE UNIVERSITY

WOODWARD-CLYDE CONSULTANTS 


\section{Name}

M. Halliwell

A. DuBois

G. West

E. P. Binnall

J. F. T. Agapito

A. J. Rambosch

J. E. Schuster

M. A. Korosec

A. Ewoldsen

S. C. Brown

W. D. Swearington

H. H. Wilson, Jr.

L. Alvarez

G. Nelson

S. Scurlock

M. W. Barnes

R. Ellison

P. Rizzo

R. Schaefer

K. Kennedy

H. R. Pratt

S. Robbins

N. J. Becar

P. A. Ellis

D. D. Baker, Sr.
Affiliation

Lawrence Berkeley

Laboratory

Self

Mining Engineering

Washington State Depart-

ment of Natural Resources

Woodward-Ciyde Consultants

Kaiser Engineering

Lynes, Inc.

United Engineers and

Construction, Inc.

Earth Science Associates

Science Applications, Inc.

The Pennsylvania State University

D'Appolonia

Schaefer Well Service, Inc.

August 16 , 17 , and 18

August 3 and 4

August 4

August 4

August 8

August 8

August 9

August 9

August 9

August 10

R. E. Gephart

August 11

S. M. Price

August 14

H. B. Dietz

R. L. Biggerstaff

Science Applications, Inc. August 18

R. E. Gephart

Terra-Tek

U. S. Geological Survey

Kaman Sciences Corporation

Gordon H. Ba11, Inc.
August 22

M. R. Kasper

August 24

R. C. Edwards

August 24

D. L. Cahow

August 28
H. B. Dietz,

B. H. Richard 
Visitors (continued)

Name

T. Abe

C. Altison

D. Eberhardt

S. McKinney

J. Hogan

B. Cummings
Affiliation

Sato Kogyo Company, Ltd.

Genstar Construction

Company

J. A. Jones Construction Company
Date

Person Contacted

August 28 H. B. Dietz,

B. H. Richard

August $31 \quad H$ Yancy

August 31 H. Yancy 
Name

M. P. Board

R. E. Gephart

H. B. Dietz

G. C. Evans

G. C. Evans

\section{To}

University of Minnesota, Minneapolis, Minnesota

Lawrence Berkeley Laboratory, Berkeley, Cal ifornia

Lawrence Berkeley Laboratory, Berkeley, California

Woodward-Clyde Consultants, August 23 San Francisco, California

Columbus, Ohio
Date Reason

August 2 Design canister arrays and heat loading parameters for the NearSurface Test Facility.

August 4 Visit the laboratory to discuss hydrologic program.

August 23 Negotiate work scope for the NearSurface Test Facility Phase I Heater Test.

Fact-finding regarding borehole plugging proposal.

August 28 Attend meeting at the Office of Nuclear Waste Isolation regarding in situ test needs. 


\section{PREVIOUS MONTH}

RH0-BWI-78-100 MAR (unclassified), March 31, 1978, R. A. Deju, "Waste Isolation Program Monthly Report"

RH0-BWI-78-100 APR (unclassified), April 30, 1978, R. A. Deju, "Waste Isolation Program Monthly Report"

RH0-BWI-C-3 (unclassified), February 1978, P. Goldstein, G. 0. Hultgren, and R. W. Nelson (Boeing Computer Services Richland, Inc.), "A Model of Contaminant Diffusion from a Finite Line Source in a Dense Basalt Stratum to an Overlying Permeable Interbed"

RHO-BWI-ST-3 (unclassified), November 1977, C. W. Myers (Rockwell Hanford Operations), F. Asaro and M. V. Michel (Lawrence Berkeley Laboratory), "A Statistical Evaluation of Some Columbia River Basalt Chemical Analyses--An Interim Report"

\section{THIS MONTH}

RH0-BWI-78-100 MAY (unclassified), May 31, 1978, R. A. Deju, "Waste Isolation Program Monthly Report"

RHO-BWI-C-10 (unclassified), March 1978, G. B. Tucker and J. G. Rigby (Washington State Department of Natural Resources, Division of Geology and Earth Resources), "Bibliography of the Geology of the Columbia Basin and Surrounding Areas of Washington with Selected References to Columbia Basin Geology of Idaho and Oregon"

RH0-BWI-LD-2 (unclassified), June 1978, M. P. Board, "Rock Mechanics Methods and In Situ Heater Tests for Design of a Nuclear Waste Repository in Basalt" 
DISTRIBUTION

Number of Copies

3 BATTELLE-OFFICE OF NUCLEAR WASTE ISOLATION

J. M. Batch

R. E. Heineman

M. Kahnemuyi

BROOKHAVEN NATIONAL LABORATORY

P. W. Levy

1

BROWN UNIVERSITY

B. Gilett $i$

CALIFORNIA ENERGY RESOURCES CONSERVATION AND DEVELOPMENT COMMISSION

W. Irving

CENTRAL WASHINGTON UNIVERSITY

Department of Geology

CONSULTANTS AND SUBCONTRACTORS

J. F. T. Agapito

Boeing Computer Services Richland, Inc.

Colorado School of Mines

Fenix \& Scisson, Inc. (2)

Geoscience Research Consultants

Idaho Bureau of Mines and Geology

Lawrence Berkeley Laboratory

Oregon State Department of Geology and Mineral Industries

F. L. Parker

The Pennsylvania State University

I. Remson

Seismograph Services Corporation

Senturion Sciences, Inc.

W. K. Summers and Associates

U. S. Bureau of Mines-Spokane

U. S. Geological Survey-Water Resources

U. S. Geological Survey-Western Division

University of Minnesota

University of Oregon

Vitro Engineering

Washington State Department of Ecology

Washington State Department of Natural Resources

Washington State University

A. C. Waters

Western Washington University

Woodward-Clyde Consultants 


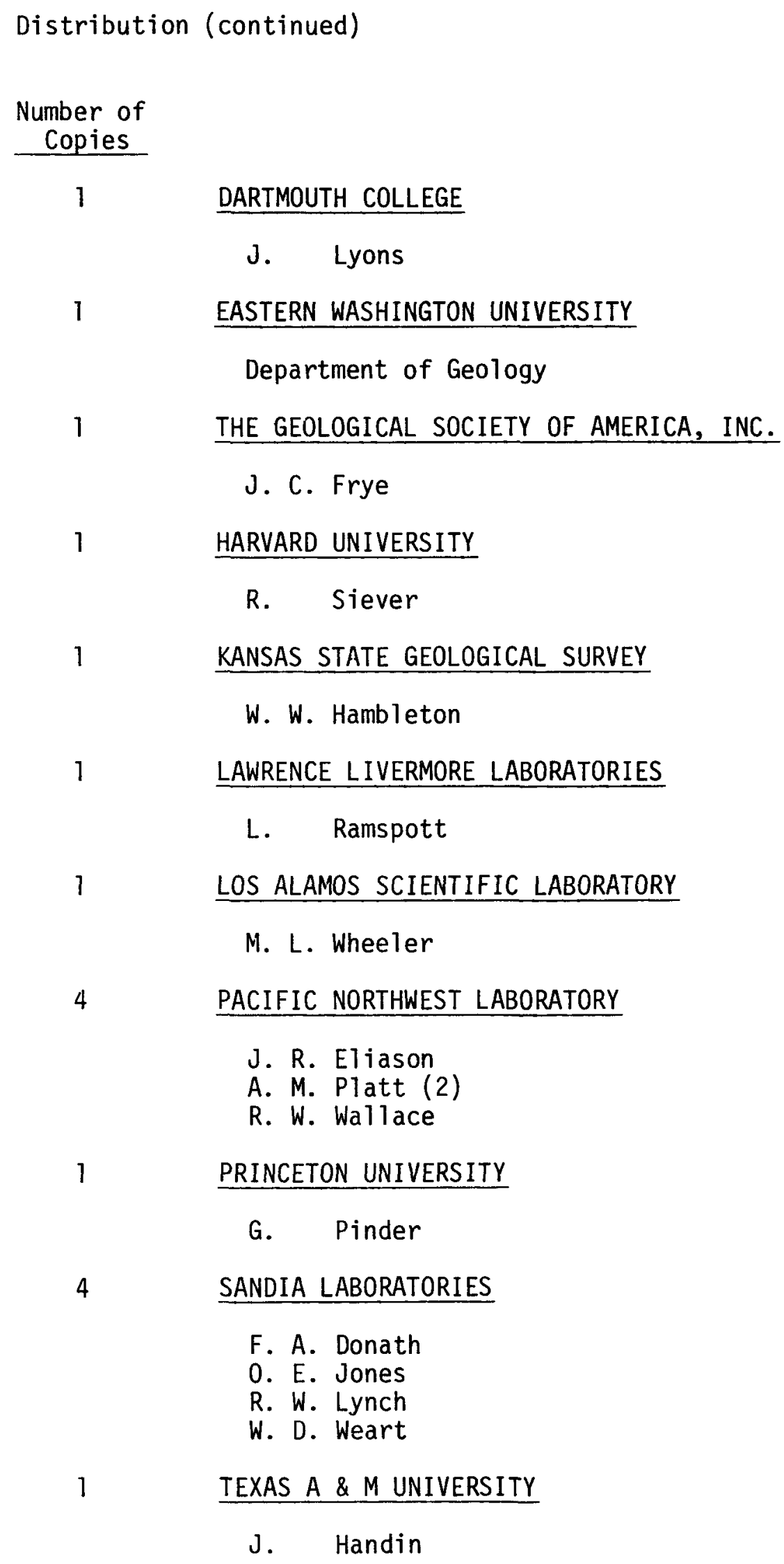

LAWRENCE LIVERMORE LABORATORIES

L. Ramspott

LOS ALAMOS SCIENTIFIC LABORATORY

M. L. Wheeler

J. R. Eliason

A. M. Platt (2)

R. W. Wallace

PRINCETON UNIVERSITY

G. Pinder

SANDIA LABORATORIES

F. A. Donath

0 . E. Jones

R. W. Lynch

W. D. Weart

1 TEXAS A \& M UNIVERSITY

J. Handin 
Distribution (continued)

Number of

Copies

1

UNION OF CONCERNED SCIENTISTS

R. Lipschutz

UNITED NUCLEAR INDUSTRIES, INC.

G. 0. Amy

1

U. S. ARMY CORPS OF ENGINEERS

Walla Walla District Geologist

U. S. BUREAU OF RECLAMATION

Columbia Basin Project Geologist

1 U. S. DEPARTMENT OF ENERGY-ALBUQUERQUE OPERATIONS OFFICE

D. T. Schueler

1

U. S. DEPARTMENT OF ENERGY-COLUMBUS PROGRAM OFFICE

J. Neff

10 U. S. DEPARTMENT OF ENERGY-HEADQUARTERS
R. H. Campbell
D. B. LeClaire
C. R. Cooley
S. Meyers
M. W. Frei
R. G. Romatowski
C. H. George
R. Stein
C. A. Heath
D. L. Vieth

U. S. DEPARTMENT OF ENERGY-NEVADA OPERATIONS OFFICE

D. G. Jackson

R. M. Nelson

U. S. DEPARTMENT OF ENERGY-OAK RIDGE OPERATIONS OFFICE

C. A. Keller

U. S. DEPARTMENT OF ENERGY-RICHLAND OPERATIONS OFFICE
J. W. Anttonen
A. G. Lassila
T. A. Bauman
D. J. Squires (4)
J. C. Cummings
F. R. Standerfer
0. J. Elgert
M. W. Tiernan
R. B. Goranson
P. S. Van Loan
P. G. Harris 
Distribution (continued)

Number of Copies

U. S. DEPARTMENT OF ENERGY-SAN FRANCISCO OPERATIONS OFFICE

J. S. Muhlestein

U. S. ENVIRONMENTAL PROTECTION AGENCY
R. Kaufman
G. L. Meyers
J. Sceva

U. S. GEOLOGICAL SURVEY

G. D. DeBuchanne

P. R. Stevens

W. S. Twenhofel

U. S. NUCLEAR REGULATORY COMMISSION

J. 0. Bunting, Jr.

J. C. Malaro

E. P. Regnier

UNIVERS ITY OF IDAHO

Department of Geology

UNIVERSITY OF WASHINGTON

Department of Geology

WASHINGTON PUBLIC POWER SUPPLY SYSTEM, INC.

D. D. Tillson

N. D. Lewis

1 WESTINGHOUSE ADVANCED ENERGY SYSTEMS

T. Hakl

WEST INGHOUSE HANFORD COMPANY

A. G. Blasewitz 
Distribution (continued)

Number of Copies

ROCKWELL HANFORD OPERATIONS

H. Babad

D. C. Barthol omew

M. Bellofatto

R. L. Biggerstaff

D. J. Brown

J. M. Carey

D. J. Cockeram

T. A. Curran

R. A. Deju

H. B. Dietz

J. W. Donahue

G. C. Evans

M. R. Fox

R. A. Freeman

P. J. Fritch

R. J. Gimera

R. D. Hammond

W. F. Heine

R. E. Isaacson

J. E. Kinzer

E. J. Kosiancic

A. D. Krug

W. P. Kunkel

W. J. Kurzeka

J. F. Marron

D. L. Martin

J. T. Meyer

R. Raphael

R. C. Roal

J. H. Roecker

J. S. Sprouse

D. A. Turner

C. T. Webster

R. T. Wilde

L. Wilhelmi

D. D. Wodrich

H. A. Zweifel

Basalt Waste Isolation Program Library (50) Document Control (4) 